Portland State University

PDXScholar

\title{
The Role of Mitochondrial Superoxide Dismutase (SOD2) During a Coxiella Burnetii Infection
}

Rachel Diantha Champaigne

Portland State University

Follow this and additional works at: https://pdxscholar.library.pdx.edu/honorstheses

Let us know how access to this document benefits you.

\section{Recommended Citation}

Champaigne, Rachel Diantha, "The Role of Mitochondrial Superoxide Dismutase (SOD2) During a Coxiella Burnetii Infection" (2015). University Honors Theses. Paper 160.

https://doi.org/10.15760/honors.168

This Thesis is brought to you for free and open access. It has been accepted for inclusion in University Honors Theses by an authorized administrator of PDXScholar. Please contact us if we can make this document more accessible: pdxscholar@pdx.edu. 
The Role of Mitochondrial Superoxide Dismutase (SOD2) During a Coxiella burnetii

Infection

\title{
Rachel Diantha Champaigne
}

An undergraduate honors thesis submitted in partial fulfillment of the requirements for the

\author{
degree of \\ Bachelor of Science \\ in \\ University Honors \\ and \\ Biology
}

\author{
Thesis Advisor \\ Rahul Raghavan \\ Portland State University
}

2015 


\section{RESEARCH QUESTION}

What is the role of Mitochondrial Superoxide Dismutase (SOD2) during a Coxiella burnetii infection in human cells? 


\begin{abstract}
Coxiella burnetii is the etiological agent of acute Q fever and highly fatal chronic endocarditis in humans. It is an intracellular bacterial pathogen that initially invades macrophages and thrives within a lysosome-like parasitophorous vacuole by modifying host processes. Expression analyses of THP-1 cells (human monocyte/macrophage cell line) using RNA-seq show differential expression of several host genes in $C$. burnetii infected cells when compared to uninfected cells. Mitochondrial Superoxide Dismutase (SOD2) expression is highly upregulated (8x) during $C$. burnetii infection as opposed to uninfected cells, but it is unknown if this expression pattern is a host immune response to suppress Coxiella growth or whether Coxiella induces it to promote its own intracellular growth. To understand the function of SOD2 during Coxiella infection in human macrophages, a targeted RNA silencing approach (siRNA) was used to knock down SOD2 gene expression in HeLa and THP-1 cells. An increase in the levels of $C$. burnetii infection would have indicated that the increased expression of SOD2 is a host response to control intracellular bacteria. Conversely, a decrease in C. burnetii numbers would have suggested that SOD2 expression is beneficial to Coxiella and is induced by the bacterium to promote intracellular growth. A significant transfection was not completed in the HeLa cell line, due to cytotoxicity of liposome delivery system. The change in bacterial growth in THP-1 cells that were transfected with a siRNA targeting the SOD2 transcript was insignificant. A gene expression analysis indicated that the success of the transfection was at about $30 \%$, and therefore did not significantly affect the bacterial growth rate. When a more successful transfection method is optimized, the question can be revisited.
\end{abstract}




\section{ACKNOWLEDGEMENTS}

As with all science, this project was met with many late nights, long optimization processes, and many setbacks and failures. During these times, my lab mates were very encouraging and supportive. They helped me to troubleshoot, forced me to step back, take breaks, and look at the problem from a different angle. They have always been there to give me a hard time, and take me out for a drink afterward. Thank you, Robyn Reid, William Scott, Jess Miller, Fenil Kacharia, Todd Smith, Melissa Holler, and Colleen Campbell. I am especially thankful for the constant help and ideas of our amazing lab manager, Abraham Moses. He helped me with techniques, was a sounding board for ideas and enhanced my intellectual growth during the process. My best friend, Jason King, was a constant source of support and encouragement, and asked me to explain what I was doing, which helped me learn how to explain complicated biological processes in layman's terms. He taught me perspective, and kept the potential real world applications of my research in my foresight.

I have been blessed with two little minions of my own. My boys have been very helpful and encouraging. They asked about my research, and proudly told others about what I was working on. They often waited up at night for me to come home, to read them their bedtime stories, and tuck them in. I have been fortunate not to miss any of their nighttime hugs. Donavon and Patrick Champaigne inspired me to work hard and contribute to the world of science. My husband, F. Jon Champaigne, has stood by my side through some tough days, but he has always encouraged me to continue on forward with my project. He reminded me that with every setback, I was learning so much more than if it had gone perfectly the first time. He is my rock, and I owe much of my sanity to him. 
My thesis professor, David Wolf, has encouraged me every step of the way. He went far beyond his job requirements. He engaged with us as students and as people, and tailored his advice to our specific needs, circumstances, and individual research. He is a great person to have in your corner when learning about the research process. My thesis advisor, Rahul Raghavan, is probably the best P.I. with whom anyone could be fortunate enough to work. He is insightful, sharp, and supportive; but more than that, he built and encouraged a team of individuals that worked closely together, on a variety of projects, and fueled a collaborative learning environment. He checked in with us frequently, during and outside of lab meetings, and has been an active part of our research; while still providing us with a great deal of independence in developing our individual projects.

I am immensely grateful to all of the other people in my life, those with a constant presence, and those who have just passed through. My coworkers at the VA, my friends, my mother, Catherine Portrey, my adoptive mother, Tess King, my 11 blood siblings, and my many step-siblings are all sources of support and drive me onward to my future. For them, and anyone not specifically mentioned above, I am so proud to have you in my life, and as a part of my research and learning processes.

Lastly, I would like to thank our funding sources, without whom none of this would be possible. The Raghavan laboratory is funded by the American Heart Association and the Oregon Health and Science University Medical Research Foundation. 


\section{TABLE OF CONTENTS}

PAGE

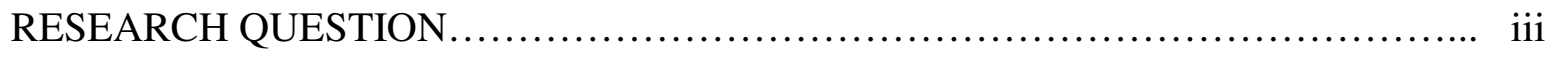

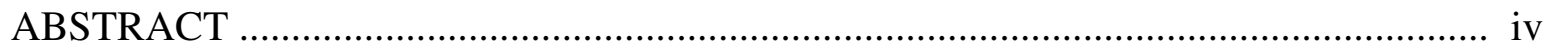

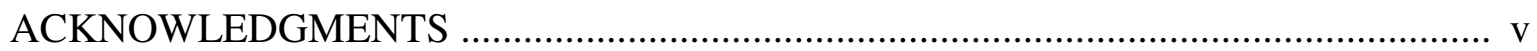

TABLE OF CONTENTS ...................................................................................... vii

LIST OF TABLES AND FIGURES …................................................................. viii

\section{CHAPTERS}

PAGE

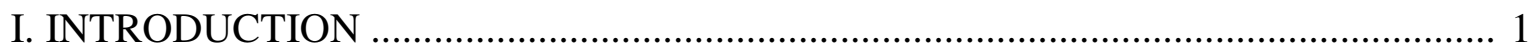

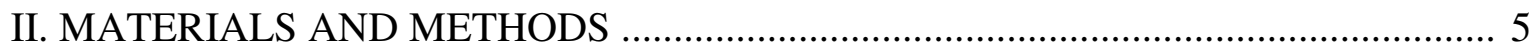

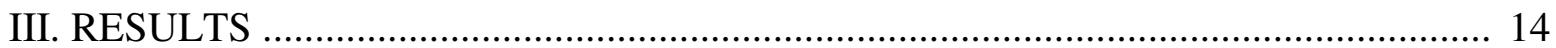

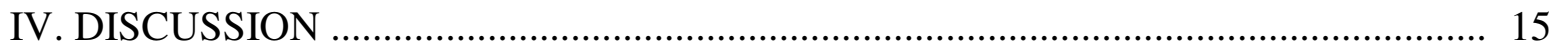

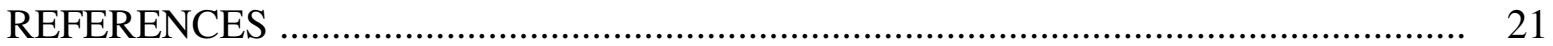




\section{LIST OF TABLES AND FIGURES}

PAGE

\section{TABLES}

1. Ingredients for ACCM2 media for growth of Coxiella burnetii 16

2. qPCR results for infected cells, transfected vs. non-transfected 17

3. Mitochondrial superoxide dismutase (SOD2) expression analysis 17

\section{FIGURES}

1. Intracellular lifecycle and modulation of host expression through protein effectors (Voth and Heinzen, 2007) $)^{3}$ 18

2. SOD2-catalyzed dismutation of superoxide.... 18

3. qPCR amplification of Coxiella growth in SOD2 and non-targeting siRNAs transfections with Coxiella and GAPDH primers

4. Dissociation curves in qPCR for SOD2 and non-targeting siRNAs transfections with Coxiella and GAPDH primers.

5. Graphical representation of SOD2 expression in SOD2 siRNA vs non-targeting siRNA transfections. .20 


\section{CHAPTER I}

\section{INTRODUCTION}

Coxiella burnetii is an intracellular pathogen that causes Q-fever and chronic endocarditis in humans. ${ }^{1}$ Coxiella is able to withstand many environmental challenges, including UV light, rapid temperature change, and osmotic stresses ${ }^{2}$. It does so through a stasis-type variant (small cell variant), which can be aerosolized and inhaled. It is typically transmitted to humans in agricultural areas with large populations of sheep or goats, though recent research has found evidence of transmission from wildlife to humans ${ }^{3}$. When Coxiella is inhaled, it is endocytosed into a phagosome (Figure $1^{4}$ ). As the phagosome fuses with an endosome and transits through the endocytic cascade, its internal $\mathrm{pH}$ drops due to the accumulation of hydrogen pumps as the membrane fuses and grows. At the end of the cascade, the phagosome fuses with the lysosome ${ }^{5,6}$.

The lysosome is traditionally the location in which all pathogens, misfolded proteins, and other cellular debris go to be broken down and recycled for the cell's needs. It is in this organelle that $C$. burnetii thrives, and replicates into both large cell variants (LCVs), the replicative form, and small cell variants $(\mathrm{SCV})$, the infective form ${ }^{7,8}$. The lysosome at this stage becomes a replicative parasitophorous vacuole (PV). During the replicative phase, the host continues to send cellular waste to the lysosome (now a PV) to be degraded. Coxiella uses the cellular waste for its own metabolic needs ${ }^{9}$. As the quantity of bacteria in the PV increases, the size of the PV membrane grows by fusing with other endocytic vesicles ${ }^{9}$. C. burnetii has a type IV secretion system with which it delivers protein effectors to the host cytosol $^{10,11,12}$. These effectors control the host's expression of specific genes; modifying cytoplasmic filament placement, apoptotic pathway, mitotic signals, lipid production, and host immune responses ${ }^{13}$. 
Changes in expression patterns of host genes can be determined through High Throughput RNA sequencing (RNA-seq) ${ }^{14}$, which is a process in which the whole transcriptome, or all cellular RNA present at one time, can be collected and analyzed. Previously, we performed an RNA-seq analysis of THP-1 cells infected with $C$. burnetii and identified several genes that were differentially expressed in infected cells compared to non-infected cells. Expression changes can be an immune response of the host to the pathogen ${ }^{15}$ or they can be a result effectors secreted by the pathogen via a type IV secretion system.

A small interfering RNA (siRNA) is a short nucleotide sequence that can bind to transcribed mRNA, either prior to or after the splicing out of introns. The siRNA can also bind to the active site of a targeted protein, inhibiting the active site and blocking interactions between it and other peptides; this may also modify the structure of the protein, interfering with its function.

To determine which host factors were involved in expression changes during a Coxiella burnetii infection in HeLa cells, McDonough et al. ${ }^{16}$ performed a whole human genome-wide siRNA knockdown, in infected and uninfected cells. This included silencing of 21,121 individual human genes in 384-well plates, then using fluorescence imaging and analysis of size and quantity of the $C$. burnetii parasitophorous vacuoles in the cells. The quantity and size of the PVs allowed for the identification of host proteins were the most important for $C$. burnetii growth within HeLa cells ${ }^{16}$. 
In our RNA-seq analysis in THP-1 cells, one gene that was found to be significantly upregulated during $C$. burnetii infection of THP-1 cells is mitochondrial superoxide dismutase $(\mathrm{SOD} 2)^{14,17}$. We found the expression of SOD2 to be upregulated by eight times the amount of an uninfected cell. This gene was not specifically discussed in McDonough's paper, though it showed a similar amount of upregulation in their supplementary data sheets.

The SOD2 protein itself is a heterotetramer that binds one manganese ion per segment. When superoxide ions are produced through normal oxidative phosphorylation processes, SOD2 uses the manganese ion to convert the superoxide radicals $\left(\mathrm{O}_{2}{ }^{-}\right)$to hydrogen peroxide $\left(\mathrm{H}_{2} \mathrm{O}_{2}\right)$ and diatomic oxygen $\left(\mathrm{O}_{2}\right)$, effectively neutralizing the reactive oxygen species (ROS). Hydrogen peroxide is then further broken down by an enzyme called catalase (figure 2).

During an infection, it is believed that the host cell makes SOD2 and stores it in the mitochondria while it initiates a full-scale superoxide attack on the pathogen, then releases its SOD2 to neutralize the superoxide after the assault so that it does not harm the host. C. burnetii is known to combat oxidative stress from host assault with antioxidants like glutathione, vitamins $\mathrm{A}, \mathrm{C}$, and $\mathrm{E}$, and carotenoids, as well as other molecular neutralizing agents ${ }^{19,20}$. It is also suspected that an acid phosphatase is secreted through $C$. burnetii type IV secretion system to neutralize the oxygen free radicals ${ }^{18}$. Superoxide dismutase could benefit the host by neutralizing the superoxide ions after the immune attack, but could instead help the pathogen if it is upregulated prior to or during the host's superoxide attack. Narasipura, Chaturvedi, and Chaturvedi showed that pathogen-derived self-upregulation of SOD2 actually contributed to the virulence of the fungi, Cryptococcus neoformans gattii, during an infection in mice, providing it with the ability to neutralize the host's superoxide attack $^{19}$. 
To determine the role of SOD2 during a Coxiella infection, we knocked down SOD2 expression in THP-1 cells using small interfering RNAs (siRNA) and quantified bacterial growth within the transfected and non-transfected cells. We hypothesized that if we reduced expression of SOD2 and it then decreased bacterial growth, SOD2 most probably benefits the pathogen, whereas if it increased the number of intracellular bacteria, the role of SOD2 is as the host's control mechanism for combating the Coxiella infection. 


\section{CHAPTER II}

\section{MATERIALS AND METHODS}

\section{Coxiella culture media preparation}

All work with whole-cell Coxiella burnetii was performed in a biosafety hood by individuals with certified training for biosafety level 2 handling. Coxiella media (ACCM-2) was made as

outlined in Table 1 . The $\mathrm{pH}$ was adjusted to 4.75 , filtered with $0.22 \mu \mathrm{m}$ pore PES membrane syringe filter and portioned for storage $(10 \mathrm{~mL}$ into $15 \mathrm{~mL}$ falcon tubes). Coxiella cells were scraped out of frozen cryo storage tube with an inoculating loop (or specified thawed PBSS stock volume) and $1 \mathrm{~mL}$ ACCM-2 media in a falcon tube was inoculated. It was then put into incubator at $37 \square \mathrm{C}$ with $5 \% \mathrm{CO}_{2}$ and $2.5 \% \mathrm{O}_{2}$ on a shaking platform, and grown for at least 3 days prior to use.

\section{HeLa cell culture media preparation}

All work with whole cell human cells took place in a cell-culture hood. For $60 \mathrm{~mm}$ culture petri dishes, HeLa cell media was made with 4.5 mL DMEM (Dulbecco minimal Eagle's medium without L-glutamine) (Invitrogen) and $0.5 \mathrm{~mL}$ fetal bovine serum and supplemental L-glutamine. The DMEM and FBS were used alone, without L-glutamine or antibiotics for dilution media when splitting cells. A 9:1 ratio of DMEM:FBS with L-glutamine was used for media for infections. For regular growth of HeLa cells, a 9:1 ratio of DMEM:FBS with L-Glutamine and Pen/Strep (Penicillin/Streptomycin) was used. Transfections took place using media with only 1\% FBS serum with L-glutamine, but without antibiotics. 


\section{THP-1 cell culture media preparation}

THP-1 Media was prepared with Roswell Park Memorial Institute (RPMI) 1640 medium with 2 mM L-glutamine, $0.05 \mathrm{mM}$ beta mercaptoethanol, and $10 \%$ fetal bovine serum (FBS). Pen/Strep

was added at $1 \%^{22}$. Media was filtered with a $(0.2 \mu \mathrm{m})$ filter prior to use to filter out any microbes from the media. Antibiotics were not used during transfection or infection, and only $1 \%$ FBS was used during transfections.

\section{HeLa cell freezer stock preparation}

Media was pulled off of cells at $\sim 60 \%$ confluency (approximately 1 million cells) and the media was discarded. Cells were washed with $2 \mathrm{~mL}$ phosphate buffered saline (PBS). The PBS was removed and cells are trypsinized with $2 \mathrm{~mL}$ trypsin and placed into incubator for 5 minutes. Trypsinization was verified in microscope, showing that no cells remained adhered to surface of plate. $1 \mathrm{~mL}$ of FBS ratio was added to the dish to stop trypsinization. Media was moved to a falcon tube. Cells were spun down to a pellet in centrifuge for 3 minutes at $500 \mathrm{rpm}$. Supernatant was removed and cells were resuspended in $1 \mathrm{~mL}$ of freezing media (1 mL DMSO: $2 \mathrm{~mL}$ FBS with L-glutamine and pen/strep: $7 \mathrm{~mL}$ DMEM). Freezing media with suspended cells was transferred to a cryotube and placed in styrofoam in a $-80 \square$ freezer overnight and transferred to liquid nitrogen cryo freezer the next day. 


\section{THP-1 cell freezer stock preparation}

Undifferentiated cells are grown to $\sim 60 \%$ confluency (approximately 1 million cells). Media used for freezer stocks have 5\% DMSO along with growth regular media. $1 \mathrm{~mL}$ solution was added to cryo tubes, which were put into styrofoam in a $-80 \square$ freezer overnight, and transferred to liquid nitrogen cryo freezer after 24 hours.

\section{Thawing HeLa cells from freezer}

The incubator was turned on and set to $37 \square \mathrm{C}$ with $5 \% \mathrm{CO}_{2}$. Frozen stock was thawed at room temperature while DMEM and FBS with L-glutamine and Pen/Strep were warmed in incubator. DMEM and FBS were prepared in a 9:1 ratio. $1 \mathrm{~mL}$ cryo-frozen HeLa cells were obtained from the Singer Lab (Portland State University). Thawed cell stock was put into a falcon tube with only DMEM and was centrifuged at 500 RPM for 3 minutes to pellet cells. Liquid was decanted into waste and 9mL DMEM and $1 \mathrm{~mL} \mathrm{FBS,} \mathrm{L-glutamine,} \mathrm{and} \mathrm{Pen/Strep} \mathrm{solution} \mathrm{are} \mathrm{added} \mathrm{to}$ resuspend the cells. Solution was added to two $60 \mathrm{~mm}$ culture dish ( $5 \mathrm{~mL}$ per dish), which were then put into incubator set at $37{ }^{\circ} \mathrm{C}$ and $5 \% \mathrm{CO}_{2}$.

\section{Thawing THP-1 cells from freezer}

The optimum cell density was $1 \times 10^{5}$ cells $/ \mathrm{mL}$ to $1 \times 10^{6}$ cells $/ \mathrm{mL}\left(\max 2 \times 10^{6}\right.$ cells $\left./ \mathrm{mL}\right)$. No more than 5 subsequent passages from freezer stock were performed ${ }^{21}$. Contents were thawed quickly and cell suspension was put into a $15 \mathrm{~mL}$ falcon tube with $5 \mathrm{~mL}$ media. The tube was centrifuged at $500 \mathrm{rpm}$ for 3 minutes. Supernatant was discarded, and pellet was resuspended in $10 \mathrm{~mL}$ media and transferred to two culture dishes $(60 \mathrm{~mm}$ culture dish $=5 \mathrm{~mL})$. Culture was kept in incubator set at $37^{\circ} \mathrm{C}$ and $5 \% \mathrm{CO}_{2}$. 


\section{HeLa and THP-1 cell culture passaging}

$1 \mathrm{~mL}$ cells were diluted in $4 \mathrm{~mL}$ total growth medium ( $5 \mathrm{~mL}$ total) and added to a $60 \mathrm{~mm}$ culture dish plating density of $15-75 \%$ confluency. Percentage confluency was determined by desired growth period for experiment. $100 \mu \mathrm{L}$ of cells are plated for each $10 \%$ desired confluency for a $60 \mathrm{~mm}$ culture plate and $20 \mu \mathrm{L}$ for each $10 \%$ desired confluency for each well of a 6-well plate. The Cell density was verified in an inverted microscope, or counted with a hemocytometer on a regular optical microscope. Culture plate with cells were placed into incubator set at $37 \square \mathrm{C}, 5 \%$ $\mathrm{CO}_{2}$, with a tray of fresh deionized water in the bottom of the incubator. Media and deionized water were changed every 2-3 days. Hela cells cannot be used for more than fifty subsequent passages from frozen stock, and THP-1 cannot be used for more than five passages, or one month's time.

\section{Differentiation of THP-1 cells}

Cells were split to desired confluency at least 24 hours prior to transfection, unless transfection took place during differentiation, or if transfection took place with suspended, undifferentiated cells. $1 \mu \mathrm{g} / \mathrm{mL}$ phorbol ester (phorbol 12-myristate 13-acetate) PMA, was added to full serum media to initiate differentiation of THP-1 cells into macrophages. Differentiation took place in plates that were used for experiment, and not in regular culture dishes. Stock PMA was kept at 5000x (5mg/mL in DMSO). $2 \mu \mathrm{l}$ of PMA solution was used for every $10 \mathrm{~mL}$ cell media. 


\section{Transfection- siRNA delivery in adherent cells (HeLa or differentiated THP-1)}

siRNA Buffer $5 \mathrm{x}$ was diluted to $1 \mathrm{x}$ by mixing with $4 \mathrm{x}$ sterile RNase-free water. Solution was pipetted up and down 3-5 times while avoiding introduction of bubbles. The solution was placed on an orbital mixer/shaker for $70-90$ minutes at $37{ }^{\circ} \mathrm{C}$ and briefly centrifuged to collect solution to bottom of the tube/wells. siRNA aliquots were made for each desired siRNA to a 200nM solution in $300 \mathrm{ul}$ of $1 \mathrm{x}$ buffer. Aliquots were stored in a $-20{ }^{\circ} \mathrm{C}$ freezer.

In a $2 \mathrm{~mL}$ tube, the transfection media was prepared with $900 \mathrm{ul}$ cell culture media (without serum). The transfection reagent was added to this volume. Lipofectamine and Dharmafect reagents were tried at a variety of volumes, as an attempt to find optimal amount of transfection while maintaining a low level of cytotoxicity, but 1ul/well of Dharmafect was the final amount used that did not have the cytotoxicity as other products and amounts. Transfection media was incubated at room temperature for 5 minutes, before being distributed, $300 \mathrm{ul}$ to each siRNA (targeting, non-targeting, and buffer only without siRNA) aliquot, which were then incubated at room temperature for 20 minutes.

Media was aspirated from adherent cells in $60 \mathrm{~mm}$ dish and disposed. $1 \mathrm{~mL}$ of trypsin was added to the dish and incubated at $37{ }^{\circ} \mathrm{C}$ for 10 minutes. $0.5 \mathrm{~mL}$ fetal bovine serum (FBS) was added to neutralize the trypsin. The dish was scraped with a cell scraper (for THP-1 cells, HeLa cells were easily removed with trypsin alone), and newly suspended cells were counted, and 
calculated to determine how much was needed to be added to achieve desired amount of cells in 6-well plate. Up to 360 ul cells in media was added, and that amount was divided by three (since it is $1 / 3 \mathrm{FBS}$ ), and the remaining amount of FBS, up to $120 \mathrm{ul}$, was added to $10.2 \mathrm{~mL}$ serum-free media, for a total $1 \%$ FBS when siRNA solution was added. $1.7 \mathrm{~mL}$ cells in media was added to prelabeled tubes, corresponding to well identifier. $300 \mathrm{uL}$ from siRNA tubes were added to corresponding tubes, with duplicate samples for each siRNA. The $2 \mathrm{~mL}$ total volume from each tube was added to its matching well. Cells were incubated at $37 \square \mathrm{C}$ with $5 \% \mathrm{CO} 2$ for 48 hours prior to infection.

\section{Transfection in suspended cells}

In a $2 \mathrm{~mL}$ tube, the transfection media was prepared with 900 ul cell culture media (without serum). The transfection reagent was added to this volume. Lipofectamine and Dharmafect reagents were tried at a variety of volumes, as an attempt to find optimal amount of transfection while maintaining a low level of cytotoxicity, but 1ul/well of Dharmafect was the final amount used that did not have the cytotoxicity as other products and amounts. Transfection media was incubated at room temperature for 5 minutes, before being distributed, 300ul to each siRNA (targeting, non-targeting, and buffer only without siRNA) aliquot, which were then incubated at room temperature for 20 minutes

The cells that were suspended in media in the $60 \mathrm{~mm}$ petri culture dish were aspirated, put into a centrifuge tube, and spun down in centrifuge at $500 \mathrm{rpm}$ for 3 minutes to pellet cells. $5 \mathrm{~mL} 1 \%$ media was added and pellet was resuspended. Cells were counted and calculated to desired amount of cells in $10.2 \mathrm{~mL} \mathrm{1 \%} \mathrm{FBS} \mathrm{media.} 1.7 \mathrm{~mL}$ cells in media was added to prelabeled tubes. 
$300 \mathrm{uL}$ from siRNA tubes were added to corresponding tubes, for duplicate samples. The $2 \mathrm{~mL}$ total volume from each tube was added to each well. Cells are incubated at $37{ }^{\circ} \mathrm{C}$ with $5 \% \mathrm{CO}_{2}$ for 48 hours prior to the Coxiella burnetii infection. Alternatively, adherent cells were plated at specified concentration of cells (THP-1 were differentiated) one day prior to transfection in $10 \%$ FBS, media was aspirated off, and transfection was completed in 1\% FBS media as outlined above.

\section{Infection of transfected adherent cells with Coxiella burnetii}

After 2-day knock-down, cells were infected with Coxiella burnetii and allowed to grow for 3 days. 100 ul of Coxiella culture in ACCM2 media, with at least 3 days growth, was added to $900 \mathrm{uL}$ cell growth media in a centrifuge tube. $10 \mathrm{ul} /$ well from this mixture was added to $13 \mathrm{~mL}$ cell media with $10 \%$ FBS. Media was aspirated off of wells, and infected media was added to wells. Plate was placed in plate bucket in centrifuge and balanced. Coxiella cells were spun down onto HeLa or THP-1 cell monolayer for $3 \mathrm{~min}$ at $500 \mathrm{rpm}$. The remaining $1 \mathrm{~mL}$ media, and the initial inoculate tube were saved for later quantification. These tubes were stored at $-80{ }^{\circ} \mathrm{C}$ until quantification. Cells in plates were placed back in incubator at $37{ }^{\circ} \mathrm{C}$ with $5 \% \mathrm{CO}_{2}$ for 3 days.

\section{Infection of transfected suspended cells with Coxiella burnetii}

100ul of Coxiella in ACCM2 and $900 \mathrm{uL}$ cell media were added to a $2 \mathrm{~mL}$ centrifuge tube. 10 $\mathrm{uL} / \mathrm{mL}$ of this solution was added to $7 \mathrm{~mL}$ of cell media, vortexed to mix, and distributed to the 6 wells. Plates were incubated at $37^{\circ} \mathrm{C}$ for 3 days. Inoculate and dilution media were stored at $80^{\circ} \mathrm{C}$ until quantified. 


\section{Quantification of bacterial growth}

For adherent cells, media was removed from wells and discarded. 250uL trypsin was added to each well and incubated for 10 minutes. Wells were scraped with cell scrapers to remove any remaining adhered cells. Cells in media was removed and spun down, then resuspended in $1 \mathrm{~mL}$ PBS. For suspended cells, cells in media were pelleted and resuspended in $1 \mathrm{~mL}$ PBS. $1 \mathrm{~mL} 0.2$ mm zirconia beads were added to bead-beating tubes. $1 \mathrm{~mL}$ cells in PBS were added to tube.

Tubes were put in bead beater for 2 minutes, cooled on ice for two minutes, and beat again for two minutes. $400 \mathrm{uL}$ supernatant was removed and put into new centrifuge tube. $400 \mathrm{uL}$ binding buffer was added to tube and mixed well. Complete $800 \mathrm{uL}$ solution was added to column from Qiagen GeneJet DNA extraction $\mathrm{kit}^{23}$. Column was centrifuged at $14000 \mathrm{rpm}$ for 1 minute and flow-through discarded. $700 \mathrm{uL}$ wash buffer was added to column and centrifuged at $14000 \mathrm{rpm}$ for 1 minute and flow-through discarded. Empty column was centrifuged for 1 minute at 14000, and placed in new tube. $30 \mathrm{uL}$ elution buffer, prewarmed to $56{ }^{\circ} \mathrm{C}$ was added to column, incubated at room temperature for 10 minutes, then centrifuged at full speed for 1 minute. Flow through elution buffer was added back to column and spun again at full speed for one minute. $2 \mathrm{uL}$ of DNA was run through qPCR, using SYBR green $\operatorname{protocol}^{23}$. 


\section{SOD2 expression analysis}

Cells that had been resuspended in PBS were pelleted down and resuspended in $250 \mathrm{uL}$ TRI, then processed as outlined in the TRI reagent protocol ${ }^{26}$. After RNA extraction, cDNA was made using Thermo Fisher cDNA protocol ${ }^{27}$. Quantitative Real Time Polymerase Chain Raction (qPCR) was conducted with SOD2 and GAPDH primers to quantify amount of SOD2 transcripts in relation to number of cells, represented by the GAPDH housekeeping gene. 


\section{CHAPTER III}

\section{RESULTS}

Table 2 shows the $\mathrm{Ct}$ values of fluorescence relating to amount of DNA increase per PCR cycle. The number indicates how many cycles were necessary to reach the indicated threshold. The A wells were run with primers specific to Coxiella, which show the amount of Coxiella DNA in each sample. The B wells were run with GAPDH - a human housekeeping gene - primers, which show how many copies of this human DNA were present in the sample. A2, A4, B3, and B5 were transfected with SOD2 siRNA. Samples A3, A5, B4, and B6 were transfected with a nontargeting siRNA as a control. The A6 and A7 wells were from the initial inoculate on the day of infection. The inoculate wells likely did not have enough DNA in the sample to produce a $\mathrm{Ct}$ value. Table 2 and Figure 3 show a small variance between the bacterial growth rates in the SOD2 siRNA and the non-targeting siRNA transfections, but the difference is not significant. Figure 4 shows a normal melt curve of both Coxiella and GAPDH primers.

Table 3 and Figure 4 show that the success of the transfection was approximately at 30\%, and that the difference between the expression rates of SOD2 in the SOD2 siRNA vs. the nontargeting siRNA were 0.7 and 1 , respectively. 


\section{CHAPTER IV}

\section{DISCUSSION}

Table 2 shows that the inoculate wells likely did not have enough DNA in the sample to produce a $\mathrm{Ct}$ value. This is likely due to the insufficient amount of time to replicate in the inoculate that the other samples had. The variance between the samples with the SOD2 transfection, versus the non-targeting transfection, are consistent, but not significant. This is consistent with the expression analysis of the SOD2 knock-down. Since the transfection only had $30 \%$ success, it had little impact on the rate of bacterial growth.

Further testing will include optimization of transfection amounts and reagents, including liposomes and possible nanoparticle delivery systems. This would help to reduce cytotoxicity, while increasing rates of transfection. HeLa cell optimization of delivery was not reached, due to cytotoxicity of Lipofectamine and Dharmafect. THP-1 cells had a successful knock-down, but the amount of change in expression was not significant enough to reach a conclusion as to whether the previously noted 8x increase in SOD2 expression was a benefit to the host or the pathogen, or the importance of this expression change during the infection. When a more successful transfection method is optimized, the question can be revisited. 


\section{TABLES AND FIGURES}

\section{TABLES}

Table 1: Coxiella ACCM-2 Media (100 mL)

\begin{tabular}{|l|l|}
\hline Componants & Amount \\
\hline Citric acid & $256.8 \mathrm{mg}$ \\
\hline Sodium citrate (2H2O) & $474 \mathrm{mg}$ \\
\hline Potassium phosphate & $50 \mathrm{mg}$ \\
\hline Magnesium Chloride (6H2O) & $20 \mathrm{mg}$ \\
\hline Calcium chloride (2H2O) & $1.32 \mathrm{mg}$ \\
\hline Iron Sulfate & $(1 \mathrm{uM})$ \\
\hline Sodium Chloride & $728 \mathrm{mg}$ \\
\hline L-cysteine (1H2O) & $26.34 \mathrm{mg}$ \\
\hline Bacto Neopeptone & $10 \mathrm{mg}$ \\
\hline Casamino acids & $250 \mathrm{mg}$ \\
\hline Methyl-b-Cyclodextrin & $100 \mathrm{mg}$ \\
\hline RPMI w/ glutamax & $12.5 \mathrm{~mL}$ \\
\hline Deionized H2O & $86.5 \mathrm{~mL}$ \\
\hline
\end{tabular}


Table 2: qPCR results for infected cells, transfected vs. non-transfected

\begin{tabular}{l|l|l|r|r|} 
Well & Well Name & Well Type & Threshold (dR) & Ct (dR) \\
\hline A2 & Cox 1f sod2 & Unknown & 7149.776 & 26.36 \\
A3 & cox 1g nt & Unknown & 7149.776 & 26.63 \\
A4 & cox2e sod2 & Unknown & 7149.776 & 26.00 \\
A5 & cox 2f nt & Unknown & 7149.776 & 26.56 \\
A6 & cox1 innoc & Unknown & 7149.776 & No Ct \\
A7 & cox1 innoc & Unknown & 7149.776 & No Ct \\
B3 & GAPDH 1f sod2 & Unknown & 7149.776 & 24.83 \\
B4 & GAPDH1g nt & Unknown & 7149.776 & 26.41 \\
B5 & GAPDH 2e sod2 & Unknown & 7149.776 & 26.14 \\
B6 & GAPDH 2f nt & Unknown & 7149.776 & 26.86
\end{tabular}

Table 3: Mitochondrial superoxide dismutase (SOD2) expression analysis

\begin{tabular}{|l|l|l|l|}
\hline \multicolumn{3}{|l|}{ Raw ct values of all samples } \\
\hline siRNA type & Sample 1 & Sample 2 & Average \\
\hline sod2 & 32.81 & 31.79 & 32.3 \\
\hline nt & 32.03 & 31.73 & 31.88 \\
\hline siRNA expression differential & dct & fold diff \\
\hline sod2 & ct & -0.5 & 0.7071067812 \\
\hline nt & 32.3 & 1 \\
\hline Adjusted rate & of expression to non-targeting siRNA rate \\
\hline & SOD2 expression & \\
\hline sod2 & 0.7 & \\
\hline nt & 1 & \\
\hline
\end{tabular}




\section{FIGURES}

Figure 1: Intracellular lifecycle and modulation of host expression through protein effectors (Voth and Heinzen, 2007)

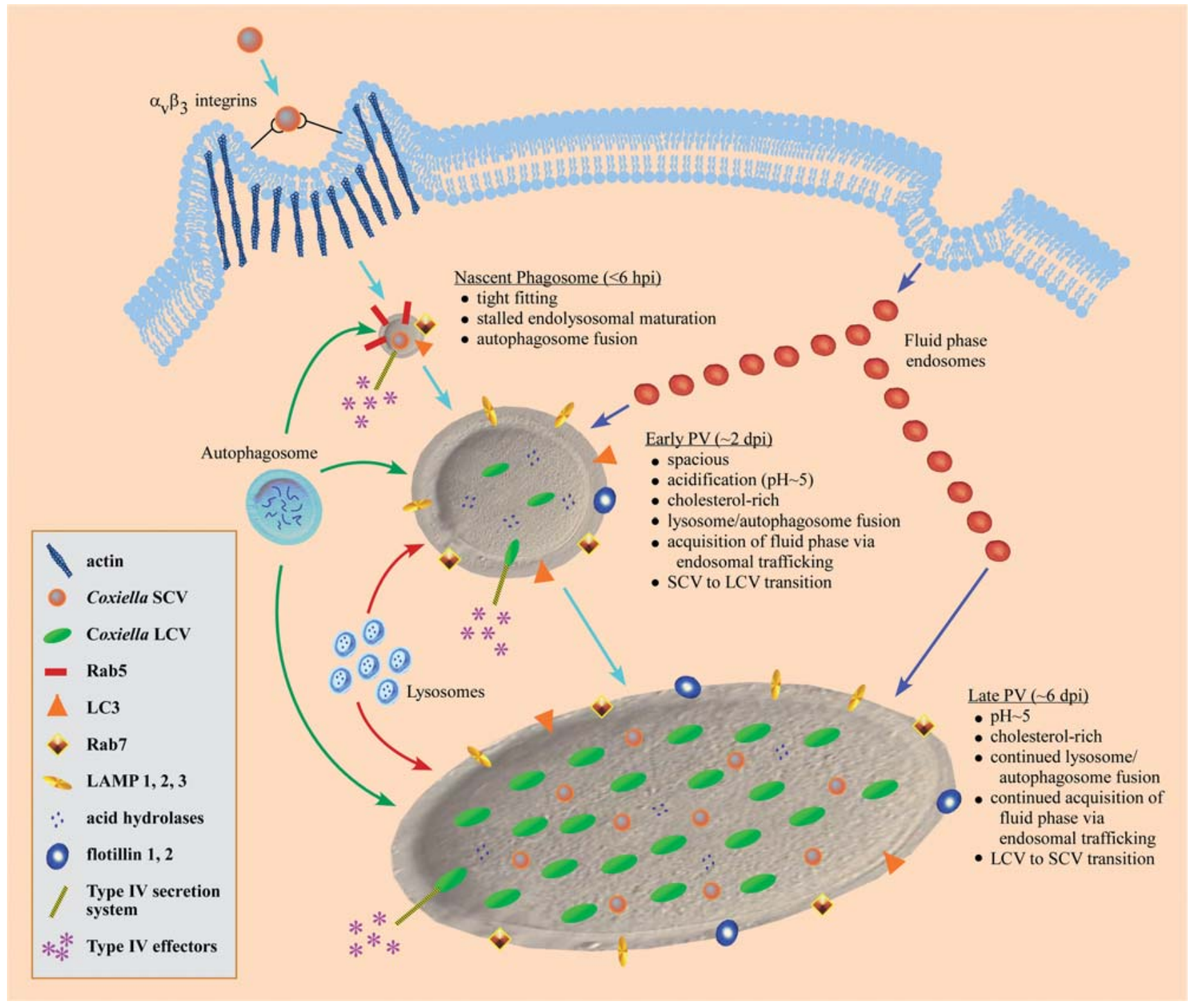

Figure 2- SOD2-catalyzed dismutation of superoxide

$$
\begin{aligned}
& \mathrm{Mn}^{3+}-\mathrm{SOD}+\mathrm{O}_{2}^{-} \rightarrow \mathrm{M}^{2+}-\mathrm{SOD}+\mathrm{O}_{2} \\
& \mathrm{M}^{2+}-\mathrm{SOD}+\mathrm{O}_{2}^{-}+2 \mathrm{H}^{+} \rightarrow \mathrm{M}^{3+}-\mathrm{SOD}+\mathrm{H}_{2} \mathrm{O}_{2} .
\end{aligned}
$$


Figure 3: qPCR amplification of Coxiella growth in SOD2 and non-targeting siRNAs transfections with Coxiella and GAPDH primers

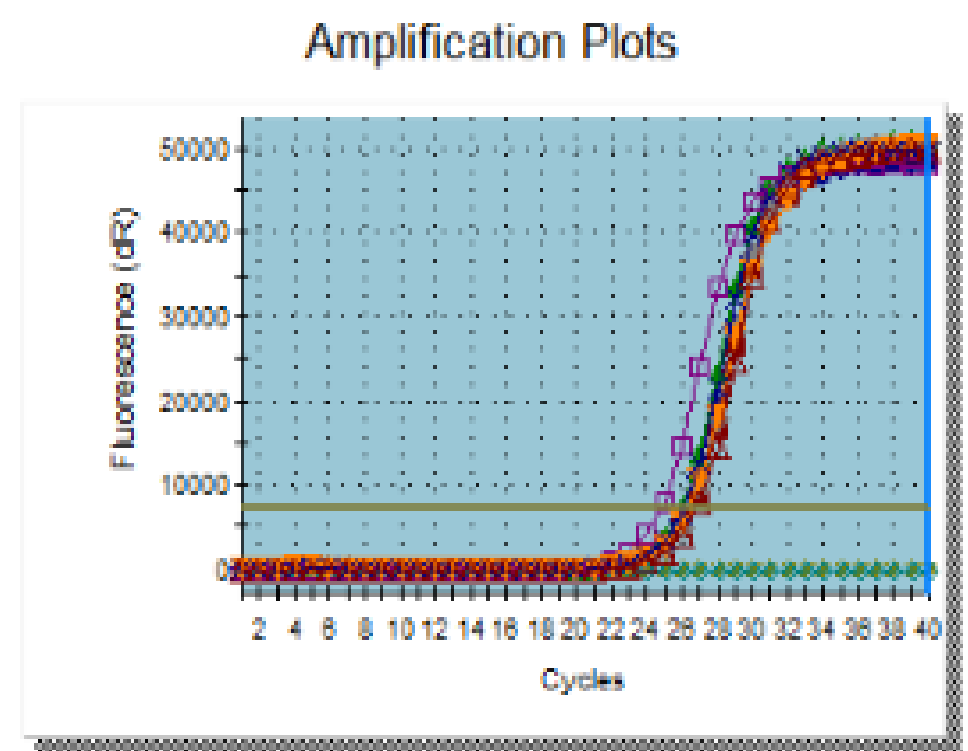

Figure 4: Dissociation curves in qPCR for SOD2 and non-targeting siRNAs transfections with Coxiella and GAPDH primers

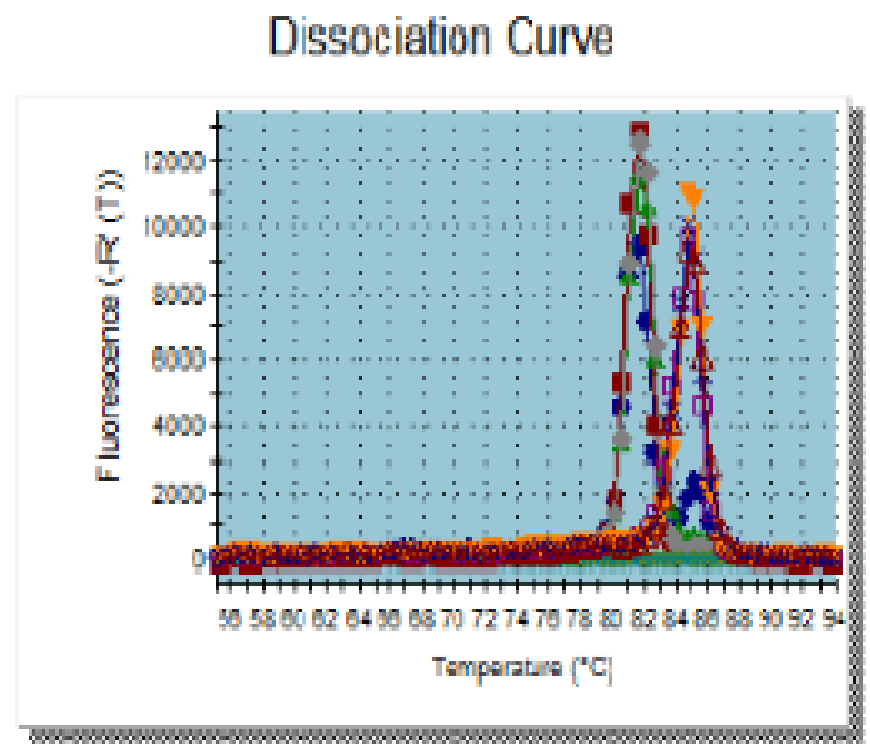


Figure 5: Graphical representation of SOD2 expression in SOD2 siRNA vs non-targeting siRNA transfections

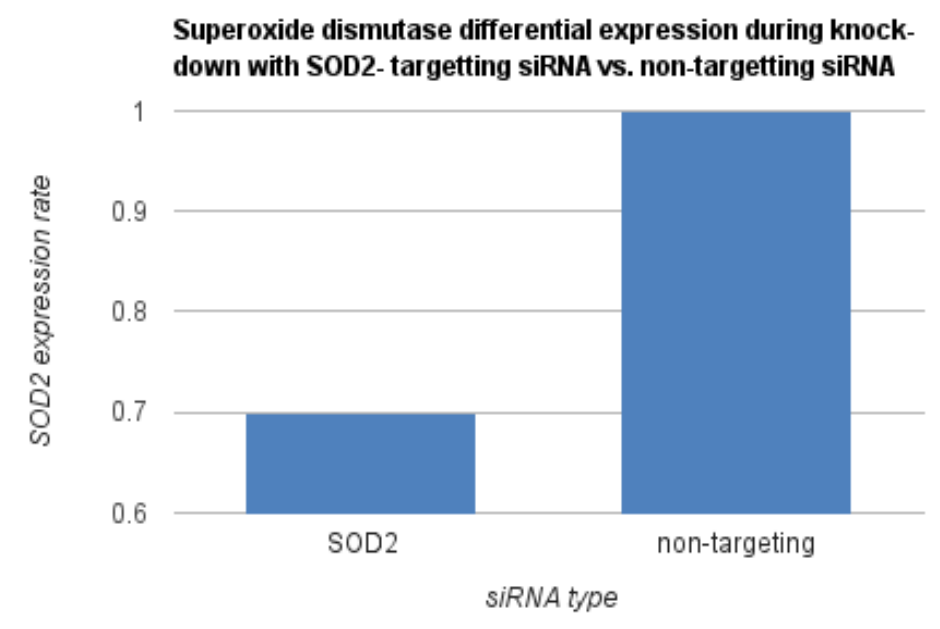




\section{REFERENCES}

1. Maurin, M., and Raoult, D. (1999) Q fever. Clin Microbiol Rev 12: 518-553

2. McCaul, T.F., Hackstadt, T., and Williams, J.C. (1981) Ultrastructural and biological aspects of Coxiella burnetii under physical disruptions. In Rickettsiae and Rickettsial

Diseases. Burgdorfer, W., Anacker, R.L. (eds). New York: Academic Press, pp. 267-280.

3. González-Barrio D, Maio E, Vieira-Pinto M, Ruiz-Fons F. Role of the European rabbits as reservoir for Coxiella burnetii. Emerg Infect Dis. 2015 Jun [5/20/2015]. http://dx.doi.org/10.3201/eid2106.141537 DOI: 10.3201/eid2106.141537

4. Voth, Daniel E., and Robert A. Heinzen. "Lounging in a lysosome: the intracellular lifestyle of Coxiella burnetii." Cellular microbiology 9.4 (2007): 829-840.

5. Baca, O.G., and Paretsky, D. (1983) Q fever and Coxiella burnetii: a model for hostparasite interactions. Microbiol Rev 47: 127-149.

6. Heinzen, R.A., Hackstadt, T., and Samuel, J.E. (1999) Developmental biology of Coxiella burnetii. Trends Microbiol 7: 149-154.

7. Kirkegaard, K., Taylor, M.P., and Jackson, W.T. (2004) Cellular autophagy: surrender, avoidance and subversion by microorganisms. Nat Rev Microbiol 2: 301-314.

8. Coleman, S.A., Fischer, E.R., Howe, D., Mead, D.J., and Heinzen, R.A. (2004) Temporal analysis of Coxiella burnetii morphological differentiation. J Bacteriol 186: 73447352.

9. Gutierrez, M.G., Vazquez, C.L., Munafo, D.B., Zoppino, F.C.,Beron, W., Rabinovitch, M., and Colombo, M.I. (2005) Autophagy induction favours the generation and maturation of the Coxiella-replicative vacuoles. Cell Microbiol 7:981-993. 
10. Christie, P.J., and Vogel, J.P. (2000) Bacterial type IV secretion: conjugation systems adapted to deliver effector molecules to host cells. Trends Microbiol 8: 354-360.

11. Carey KL, Newton HJ, Lührmann A, Roy CR (2011) The Coxiella burnetii Dot/Icm System Delivers a Unique Repertoire of Type IV Effectors into Host Cells and Is Required for Intracellular Replication. PLoS Pathog 7(5): e1002056.

doi:10.1371/journal.ppat.1002056

12. Redd, T., and Thompson, H.A. (1995) Secretion of proteins by Coxiella burnetii. Microbiology 141: 363-369.

13. Roman, M.J., Coriz, P.D., and Baca, O.G. (1986) A proposed model to explain persistent infection of host cells with Coxiella burnetii. J Gen Microbiol 132: 1415-1422.

14. Raghavan, Rahul; Miller, Jess. laboratory research paper in progress

15. Eisenreich W, Heesemann J, Rudel T and Goebel W (2013) Metabolic host responses to infection by intracellular bacterial pathogens. Front. Cell. Infect. Microbiol. 3:24. doi: 10.3389/fcimb.2013.00024

16. McDonough JA, Newton HJ, Klum S, Swiss R, Agaisse H, Roy CR. 2013. Host pathways important for Coxiella burnetii infection revealed by genome-wide RNA interference screening. mBio 4(1):e00606-12. doi:10.1128/mBio.00606-12.

17. Mahapatra, S., Ayoubi, P. and Shaw, E. I.(2010). Coxiella burnetii Nine Mile II proteins modulate gene expression of monocytic host cells during infection. BMC Microbiol. 10, 244. doi:10.1186/1471--2180--10--244

18. Akporiaye, E T, and O G Baca. "Superoxide Anion Production and Superoxide Dismutase and Catalase Activities in Coxiella Burnetii." Journal of Bacteriology 154.1 (1983): 520-523. Print. 
19. Narasipura, S. D., Chaturvedi, V. and Chaturvedi, S. (2005), Characterization of Cryptococcus neoformans variety gattii SOD2 reveals distinct roles of the two superoxide dismutases in fungal biology and virulence. Molecular Microbiology, 55: 1782-1800. doi: 10.1111/j.1365-2958.2005.04503.x

20. Siemsen DW, Kirpotina LN, Jutila MA, Quinn MT. 2009. Inhibition of the human neutrophil NADPH oxidase by Coxiella burnetii. Microbes Infect. 11:671- 679.

21. Hill, J., and J. E. Samuel. "Coxiella burnetii acid phosphatase inhibits the release of reactive oxygen intermediates in polymorphonuclear leukocytes." Infection and immunity 79.1 (2011): 414-420.

20. Stokes, Richard W., and Daniel Doxsee. "The Receptor-Mediated Uptake, Survival, Replication, and Drug Sensitivity of $<\mathrm{i}>$ Mycobacterium tuberculosis $</ \mathrm{i}>$ within the Macrophage-like Cell Line THP-1: A Comparison with Human Monocyte-Derived Macrophages." Cellular immunology 197.1 (1999): 1-9.

21. Mae, M.B. Wittig, B., S. Highly Efficient Transfection of Human THP-1 macrophages by Nucleofection. J. Vis. Exp. (91), e51906, doi:10.3791/51960 (2014)

22. R. Boom, C.J. A. Sol, M.M. M. Salimans, C.L. Jansen, P.M.E. W. Dillen, J. van der Noordaa, Rapid and simple method for purification of nucleic acids. J. Clin Microbiol. 28(3), 495-503 (March 1990).

23. Lovatt, A., et al., Validation of Quantitative PCR Assays, BioPharm., March 2002, p.2232 See more at: http://www.sigmaaldrich.com/technicaldocuments/protocols/biology/sybr-green-qpcr.html\#sthash.GnKFGHeN.dpuf

24. Chomczynski P. A reagent for the single-step simultaneous isolation of RNA, DNA and proteins from cell and tissue samples. Biotechniques. 1993;15(3):532-4. [PubMed] 
25. Reductively Labile PRINT Particles for the Delivery of Doxorubicin to HeLa Cells Robby A. Petros, Patricia A. Ropp, and Joseph M. DeSimone Journal of the American Chemical Society 2008130 (15), 5008-5009 DOI: 10.1021/ja801436j 